\title{
Health education practices of poisoning prevention for child in Family Health Strategy
}

Práticas educativas para prevenção da intoxicação infantil na Estratégia Saúde da Família Prácticas educativas para prevenir la intoxicación infantil en la Estrategia Salud de la Familia

Camila Cristiane Formaggi Sales ${ }^{1}(\mathbb{C}$ Magda Lúcia Félix de Oliveira ${ }^{1}(10)$

1. Universidade Estadual de Maringá. Maringá, PR, Brasil.
Corresponding author:

Camila Cristiane Formaggi Sales.

E-mail: camila_cfs14@hotmail.com

Submitted on 05/05/2018

Accepted on $12 / 23 / 2018$.

DOI: 10.1590/2177-9465-EAN-2018-0140

\section{Abstract}

Objective: To analyze health education practices developed by health professionals of the Family Health Strategy team in the context of childhood poisoning. Method: Qualitative research, carried out during the months of July and August 2016, with 50 health professionals from nine Family Health Strategy teams of the city of Maringá-Paraná. Data were collected through semi-structured interviews and, subsequently, submitted to the thematic content analyses. Results: There were different perceptions and living experiences among uniprofessional or multi-professional members of the team. Those were built by different professiona categories that were working with families developing prevention activities about childhood poisoning. Those activities in groups of health education were intended to bring health professionals closer to the Users, through dialogue. Conclusion: Indeed health education practices were based on the concept of first aids, and adopting a biomedical perspective. A little discussed of poisoning accident prevention during childhood showed that those practices were away from a dialogical health education.

Keywords: Child Health; Poisoning; Primary Health Care; Accident Prevention; Health Education; Nursing.

\section{RESUMO}

Objetivo: Analisar as práticas educativas realizadas por trabalhadores da equipe da Estratégia Saúde da Família no contexto da intoxicação infantil. Método: Pesquisa qualitativa, realizada em julho e agosto de 2016, com 50 trabalhadores de nove equipes da Estratégia Saúde da Família de Maringá-Paraná. Os dados foram coletados por meio de roteiro de entrevistas semiestruturadas e posteriormente, submetidos à análise de conteúdo temática. Resultados: Interpretou-se que houve diferenças nas percepções e vivências uniprofissionais ou multiprofissionais no trabalho com as famílias e no desenvolvimento de atividades preventivas para intoxicação infantil nas diferentes categorias profissionais. As atividades em grupos de educação em saúde foram vistas como aquelas que mais aproximam o trabalhador de saúde do usuário, por meio do diálogo. Conclusão: As práticas educativas estavam pautadas em conceitos de primeiros socorros, adotando uma perspectiva curativista, e pouco discutiam a prevenção dos acidentes e intoxicações infantis na perspectiva dialógica.

Palavras-chave:Saúde da criança; Envenenamento; Atenção Primária à Saúde; Prevenção de acidentes; Educação em saúde; Enfermagem.

\section{REsumen}

Objetivo: Analizar las prácticas educativas realizadas por trabajadores del equipo de la Estrategia Salud de la Familia en e contexto de la intoxicación infantil. Método: Investigación cualitativa, realizada en julio y agosto de 2016 con 50 trabajadores de nueve equipos de la Estrategia Salud de la Familia de Maringá-Paraná. Los datos fueron recolectados por medio de un guión de entrevistas semiestructuradas y posteriormente sometidas al análisis de contenido temático. Resultados: Se interpretó que existían diferencias en las percepciones y experiencias uniprofesionales o multiprofesionales para trabajar con las familias y en el desarrollo de actividades preventivas para la intoxicación infantil en las diferentes categorías profesionales. Las actividades en los grupos de educación para la salud fueron vistas como aquellas que acercan al trabajador de salud al usuario, a través del diálogo. Conclusión: Las prácticas educativas estaban pautadas en conceptos de primeros auxilios, adoptando una perspectiva curativista y poco discutían la prevención de accidentes y las intoxicaciones infantiles en una perspectiva dialógica.

Palabras clave: Salud del Niño; Prevención de Accidentes; Intoxicatión; Atención Primaria de Salud; Educación en Salud; Enfermería. 


\section{INTRODUCTION}

Poisoning during childhood has been highlighted as an emerging public health problem and one of the causes of care in emergency health services. ${ }^{1}$ The prevention of poisoning in childhood is the focus of investigations with the assumption of knowing the causal factors and characteristics of accidents, households and family behavior, such as lifestyle, health education, economic, social and cultural factors. ${ }^{2,3}$

Literature review developed for a theoretical grounding of this study showed that few are the studies that analyze the way of caring for preventing accidents in the childhood, mainly child poisoning, by Primary Health Care (PHC) in the dialogic perspective and aiming the development of a critical consciousness. Studies that analyzed care to child poisoning, in the majority, adopted a curative and hospital-centered medical care model, with little focus on health education practices of health professionals in the sense of prevention.

However, the renewal of health education practices developed by health professionals can improve a poisoning prevention of accidents, bringing a continuous health condition and the possibility of becoming sick in the "real world", disrupt an insecure environments and fragile regulatory policies. For this, it is essential the understanding of the health professionals on proposals of education action directed to the empowerment. ${ }^{4,5}$

The present study is organized in the perspective that the health education practice of professionals from Family Health Strategy (FHS) must go beyond guidelines and prescriptive discourses, detecting vulnerabilities and social and family risk factors, ${ }^{6}$ in strategies centered in active methodologies to prevent child poisoning. It is corroborated the idea that the search for knowledge in health must approach the practice of health care since health professionals use the teaching-learning process in all their care actions. ${ }^{7,8}$

Thinking the education action as a priority axis of health care, professionals need to incorporate health education abilities in the formal spaces. Every health education action expresses an opportunity to develop comprehensive care for people's health, with priority being given to the territorially based care of families and population groups. ${ }^{9}$ To work in this scenario, health professionals need to reflect on family health care and use effective technologies in the face of the complexity involved in the interaction between families, health professionals, and society. ${ }^{10,11}$

At the same time, actions to promote health in the FHS constitute an inclusive path of care based on technical, scientific, cultural and popular knowledge, capable of bringing about individual, family and community changes. The concept of Health Education is linked to Health Promotion and presupposes that families are emancipated to decide their daily lives and their own destinies, and not only in processes that include people at risk of illness. ${ }^{12}$
Considering that the presented theme still is little studied in the national and international scientific literature, the present study aimed to analyze health education practices developed by team professionals of Family Health Strategy in the context of child poisoning.

\section{METHOD}

Qualitative, descriptive research with case study characteristics, developed in the city of Maringá - Paraná, with professionals from the PHC network, composed by 74 FHS teams, referenced by 35 primary health care units (PHCU) and nine Support Centers for Family Health (SCFH).

Brazilian FHS teams are composed by, at least, generalist physician or one specialized in family health, generalist nurse or one specialist on family health, nursing assistant or technician and health community agents (HCA). ${ }^{13}$ The SCFH is configured by multi-professional teams that act on the integrated way with Family Health Strategy teams, as a priority focus to amplify health prevention and promotion actions on primary health care. ${ }^{13}$

A lottery was held to select nine PHCU, one of each SCFH, and for the PHCU that had more than one team, a lottery was held inside the PHCU to choose one team. 50 health professionals that integrated nine teams of FHS participated in the study. It was a total of nine nurses, seven nursing assistants, and 34 HCA. Choosing these professionals was justified by their strategic functions related to direct contact with the population, such as identifying risk situations and developing health promotion and prevention actions. ${ }^{13}$

Data collection was a semi-structured interview guide composed by two phases: interviewee Socio-demographic and professional profile; and child poisoning prevention activities by professionals from the FHS teams, with triggering questions: Have you already received training on preventing poisoning? What is your experience with the theme of child poisoning? Do you feel ready to develop health education activities to prevent child poisoning with families/caretakers from the team's coverage area? In your perception, is the team that you work with prepared to prevent child poisoning?

FHS team professionals were invited personally by the researcher to participate in the study, having interviews scheduled according to the time and place each interviewee was available. There were rescheduled interviews in the cases the worker was not available due to work demands or other reasons. Interviews lasted an average of 30 minutes, they happened in the $\mathrm{PHCU}$ of each FHS team, with the minimum external influence and were fully recorded in digital media by audio and developed the field diary register to assure data trustworthiness. Interviews were developed and transcribed also by the main researcher.

Data collection happened in the months of July and August of 2016. Inclusion criteria were: to be a nurse, a nursing assistance or an $\mathrm{HCA}$, that worker in the FHS team for longer than 
12 months, independently the time of work in the FHS team which he/she acted in the moment of the interview. Exclusion criteria were: professionals who were separated from the activity during the period of data collection - vacation, health leave, maternity leave, special leave or other legal leave.

Data of professionals' characterization were organized in an electronic spreadsheet in the Software Microsoft Office Excel 10.0 and analyzed descriptively. Recorded audio was transcribed fully, typed in a text document using o Software Microsoft Office Word 10.0, and interviews were analyzed through content analysis technique, in the thematic model, with the following steps: pre-analysis, material exploration, and treatment of results/ inference/interpretation. ${ }^{14}$

The grouping of words and expressions was done initially for the later codification of the common nuclei of meanings, reduction, and simplification of the unit of analysis and synthesis of the theme. Five themes were identified: training for the practice of prevention, unit-professional or multi-professional qualification, professional experience in the attendance, the experience of the professionals with the theme and the actions taken by them in the prevention of child poisoning. Later, common emerging themes were grouped and organized highlighting the category: Health education practices in the context of child poisoning prevention. The material interpretation was developed in the light of Freire ${ }^{7}$ through a dialogic and critical perspective of healthcare.

The study was approved by the Research Ethics Committee under the, sob CAAE nㅇ5 53559316.3.0000.0104 and feedback no $1.573 .858 / 2016$. To guarantee the anonymity of the professionals, the lines were identified by codes with initials of the professional category and Arabic numbers referring to the transcription segment of the interview: "Nurs1", "Assit1", "HCA1".

\section{RESULTS}

Forty-six interviewed professionals were female (92\%), with an average age of 42,6 years old and concentration between 30 to 49 years old, an average of work experience in health services were of 10,5 years and 9,2 years of acting on family health teams. Most of HCA $(70,6 \%)$ had completed high school even if the minimum schooling required to exercise work in this category is the elementary school, and $77,8 \%$ of nurses were qualified through lato sensu graduate courses.

However, $13(26 \%)$ professionals referred to have participated in training courses to begin activities in the FHS, and only eight $(16 \%)$ indicated to have been trained to develop poisoning prevention activities, even though they all said they participated in continuous education courses with frequency, at least every four months on exercising activities.

\section{Health education practices in the context of child poisoning prevention}

Considering the training for the practice of prevention of child poisoning, the professionals reported that they act mainly with reference to the knowledge based on the daily practice of their lives and less on qualification courses and continuing education. They were mothers, caregivers of their own children and the family and had long experience working at the ESF, allowing an inter-professional relationship and exchange of knowledge.

Prepared by our experience, not by courses or scientific guidelines. Only by our experience at home. (Assist1).

We are already a mother who raised the kids, we already know everything that can leave to the child's reach or not, (Assist2).

[...] many years of work, of experience, of coexisting with the nurse and the doctor. So there is always a conversation here and there and we end up acquiring experience (HCA17).

[...] by the time we already work in health, we are learning a lot. Also, many are mothers and those who are mothers learn a lot (HCA30).

The perception of qualification for work with families on preventing child poisoning was considered a deficit for 20 $(40 \%)$ interviewed professionals. The absence of courses or training directed to child poisoning was indicated as a barrier to professional practice. The professionals informed that they developed health education practices for poisoning care, but they also admitted difficulties in providing guidelines in all kinds of toxicological hazard and that need more knowledge about the theme, with a constant update.

\section{[...] We did not have training. I believe everyone finds difficult to advise correctly. (HCA8).}

I think there is a lack of guideline. There is a course missing to help us with guidelines (HCA23).

Four professionals received training to prevent child poisoning and used the knowledge acquired in training. However, instead of preventive practices, the knowledge informed was related to the first aids to children and families in primary care, when the toxicological event have happened and, in some situations, first aids measures informed were not according to scientific evidence.

I use always this knowledge. I don't know what's new, but what I learned in the undergraduate times, we try to put it into practice when needed. There is always a case of poisoning. (Nurs9).

[...] I already have used the acquired knowledge with my daughter, because they say you can't give the person anything to drink. For example, if one drinks, you have to rush to the hospital or call the urgency mobile service. (HCA9). 
I use it always. If it's because of medication ingestion we provoke vomit, if the substance is acid, to provoke the vomit can be worse. (Nurs7).

Although the study is based on preventive practices, nurses and a nursing assistant reported some kind of experience in the professional care of poisoning.

[...] I had the experience when I got in the master's and when I worked in an emergency room. When I worked in a hospital, we cared for poisoning cases. (Nurs1).

It was more in a hospital level. Here, I got two cases and thought it was interesting to call a mobile emergency service and the child was taken to an emergency room. (Nurs8).

Here we never see it. When I worked in the neonatal intensive care unit, we had a lot of children with exogenous poisoning (Assist3).

Analyzing the perception of the multi-professional team and its qualification to act in the prevention of child poisoning, the HCAs were cited as less qualified by nurses and nursing assistants and self-referred deficiency to address the issue.

[...] They came from the community and started working here in healthcare. The Health Secretary offered them training but it was related to the work process, the dynamic and visits. Because of this, I believe they are not prepared. (Nurs1).

[...] About the nursing professionals and the physician, I believe they are prepared but the HCAs aren't, especially because they don't have any training in health. I believe they only have their experience through empirical knowledge, nothing scientific (Assist1).

Unfortunately, we are not trained because our training is very scarce. (HCA7).

The experience with the child-poisoning theme was considered "none" by 31 professionals; no nursing assistant considered their experience as satisfactory. Health professionals recognize the importance of child poisoning prevention, but they admit not them nor the managers have discussed the theme.

To tell the truth, it is the first time, we are talking about this [about child poisoning] in three and a half years that I am here (HCA13).

[...] There are few cases to the primary care and even the story reported by HCA is not a lot. (Nurs3).
Interviews that discussed the health education practice were coded, from parameters established by the authors in 1) health education practices with a focus on health promotion and family inclusion and 2) health education practices focused on the prevention of diseases and harms.

Figure 1 presents actions that enable the health education practice, informed by nurses, nursing assistants and HCA. 13 actions were cited, however, we found few reports on activities about the conception of healthy and safe habilitation, of a health promoting school and about the effective role of family and it's appreciation that should be included in the teams' health education practices in health.

Figure 1. The education health practice of nurses, nursing assistants, and HCA. Maringá-Paraná, June to August 2016. Source: The Authors, 2016.

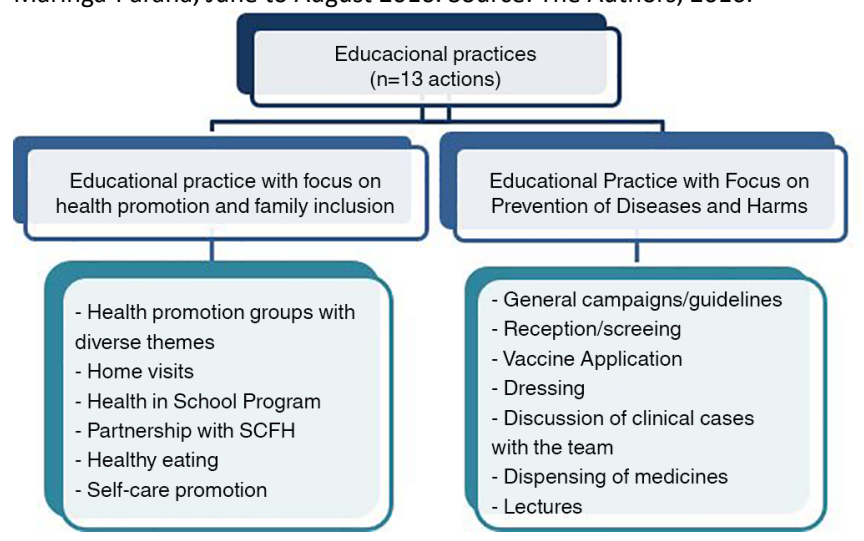

There were differences in actions informed by the health professionals. The main reported actions were group activities of health education with diverse themes, interaction with families in-home visits, and intensification/guidelines campaigns with different themes. Four HCAs informed they do not develop any type of health education activities in their work practice.

In the practices that had the objective of promoting health and family inclusion, the most cited were activities in health promotion groups with different themes, but the health professionals' statements explained that these groups are organized by specific themes and unrelated to the everyday practice.

We have a Health Group by Day, to follow up [cases of] hypertension and diabetes. There's the Smoking group, the pregnant women group. These are the groups we provide collective health education. (Nurs1).

[...] The epidemiology sector passes to us what is the biggest problem at that moment and we go out doing orientation in the groups (HCA6).

Most of the time the demand comes from the health department and does not match the local demand (Nurs9). 
Home visits were highlighted, mainly by HCA, as an opportunity for health education practices with a focus on health promotion and family inclusion.

On home visits, there is always something you have to talk about. You are not only going there to see if the family is alive, for example. You end up advising them on something. (HCA9).

On visits, we also advise. We arrive in the family's home and the person talks, exposes his/her problem or something s/he wants us to advise (HCA10).

On practices that had prevention of diseases and harms as focus, general campaigns/guidelines were the most cited by the health professionals. As well as groups of health education, intensification/guidelines campaigns with diverse themes were directed by the epidemiological situation and the emergence of diseases.

We invited for the prevention campaign. For example, we have to do a breast cancer prevention campaign because there are many cases in the country and now we are making a dengue one also (HCA3).

In the houses, we do part of the prevention related to dengue in any stage the epidemic is, and depending on the Ministry campaigns, for example, the influenza $A$ and now we even advise on chikungunya (HCA8).

\section{DISCUSSION}

We verified the socio-demographic characteristics of the health professionals in view of the influence of these variables in the health education practices to prevent child intoxication. In this sense, it was verified that the socio-demographic characteristics corroborate data on the composition of the health workforce in Brazil - females, youth, schooling above that required for the professional exercise and increase of health professionals with lato sensu graduate courses. ${ }^{15}$

However, we found fragilities on considering permanent education as a strategy to reach the development of the relationship between work and education, as a factor to increase the quality of care. ${ }^{5}$ Health professionals, although working for a long time in health services, reported little training in activities to prevent child poisoning, lack of introductory courses to join the Family Health Strategy teams, and little participation in courses and training.

However, the prevention of child poisoning is still a mystery for the health professionals interviewed, because many of them associate it with first aid, stating that they received guidance on how to proceed in the poisoning treatment at the hospital level. ${ }^{16}$ On the other hand, those who claimed to have knowledge for effective practices to prevent accidents and poisonings justified their answers based on work experience and empirical knowledge and understood child intoxication as the care of their own children and nephews.

The perception of being professionally qualified for health education activities with a view to approaching families for the prevention of child poisoning was also negative and for this reason, used common sense and inadequate popular knowledge in their practices. Probably because of these circumstances, informed prevention strategies were based on first aid measures and were not always in accordance with scientific evidence, and some initial care practices were contraindicated by toxicological assistance centers. ${ }^{17}$

Inadequate professional beliefs, such as induction of vomit/ emesis, contraindicated in all cases of poisoning for favoring the pulmonary aspiration from the gastric content, which can complicate or aggravate the child's clinical evolution. ${ }^{18}$ When prevention of exposure to toxic agents is not achieved, early and effective treatment after poisoning should be a priority, and health professionals trained for effective measures in toxicological emergencies, which was also not observed in the studied group. ${ }^{19}$

Even those who had the opportunity to attend courses that addressed the issue of child intoxication, information for health education practice was "diluted" within the curative discussion. This practice reflects the biomedical model still present in the daily life of the Brazilian health services, in a contradictory process of advancement and regression to the health promotion model, with education and health professionals trained in the use of proactive health education practices and people under the care of this process. ${ }^{7,9,16}$

In this study, some health professionals reported experience with child intoxication care, however, the majority of this experience happened at the hospital level. For this reason, health professionals use health education practices focused on the curative biomedical model, different from those advocated by the National Policy for Health Promotion. ${ }^{20}$

Considering the role of the multi-professional team of the $\mathrm{FHS}$ and its qualification to act in the promotion of health and prevention of infantile poisoning, the HCA, which use different technologies in the care process, belong to the same community as the family that receives the care and are element of between the population of the territory and the totality of the team, ${ }^{21,22}$ were the health professionals cited by nurses, nursing assistants and by them, as the lass trained for these actions. But the change of attitude of this understanding is made difficult by the historical influence of the fragmentation of the health professions and the value attributed to the different health professionals.

Teamwork in the FHS consists of a collective work modality, being configured in a reciprocal relationship between the technical interventions and the interaction of its agents. The action of health community agents, when operated in partnership with other members of the FHS team, is fundamental for teamwork 
processes, since they are, at the same time, members of the community and members of the health organization. ${ }^{21,22}$ However, it is known that the effectiveness of interdisciplinarity in health should distance itself from the hierarchy of power instituted by the curative and hospital-centered medical-assistance model. ${ }^{23}$

HCA themselves also indicated a certain inferiority facing the nurse on reporting that only graduate level health professionals are capable of acting on child poisoning prevention, distancing themselves from an interdisciplinary perspective. In general, the production of healthcare is materialized through the interaction of several diagnostic-therapeutic approaches and involves a set of knowledge and practices developed by different groups in different contexts and is not, therefore, an exclusive action of a certain professional category. ${ }^{22}$ In this sense, the knowledge from the personal experience of nursing assistants and HCA should be considered for the collective knowledge construction.

The activities developed by the health professionals of this study are still focused on the disease and with traditional methodologies, such as in health education practices focused on the prevention of diseases and diseases. However, the data also indicate actions to promote health, and inclusion of the family. Although the development of activities focused on the prevention of diseases and diseases is important in the face of epidemiological changes in health, health education practices aimed at health promotion and inclusive to the family express the opportunity to develop integrated healthcare in the face of complexity and interaction among users, families, health professionals and society. ${ }^{11}$ These health education practices are directed to the transformation of the behaviors of the people to act with autonomy in the improvement of their quality of life and health. ${ }^{7,9}$

The group health education actions, cited by most health professionals, are encouraged in the FHS and when conducted properly, with the involvement of the multi-professional team and in a reflexive perspective, facilitate the collective construction of knowledge, reflection on the reality experienced by the members of the group, favors participation popular and empower them to act in processes that aim at autonomy/self-care, as well as other activities that enable active listening, dialogue and the construction of personal and family autonomy. ${ }^{4,5}$

The home visit, considered as an opportunity for health education practice, presents itself as one of the instruments of apprehension of social reality since it makes possible the knowledge of the daily life of the families and their relations with the community. The importance of valuing the apprehension of this reality is justified by common sense in believing that the home is the safest place for the family, but most child accidents, including poisonings, occur in or around the home. ${ }^{24}$ The residence can be especially insecure for children, as it contains objects and materials at all risk, such as cutting tools, furniture, windows, cooking pots, matches, medicines, detergents and other toxic products, which are special attractions for children, and the younger it is, the higher the incidence of these episodes. ${ }^{24}$

It is up to health professionals, especially nurses, to develop health education practices with these individuals in home care to identify risk environments. ${ }^{8}$ However, in this study, nurses did not cite interaction with families in home visits as an opportunity to promote health and prevent poisoning. Regarding the importance of the HCA in the home visit, it is during this activity that the reception and the bond are established and strengthened, highlighting the possibility of constructing a dialogue, knowing the needs of the families and assisting in the resolution of the problems encountered. Also, it is in the home visit that the possibility arises to encourage the independence of the community and the families regarding their own health production, as well as the prevention of infantile poisoning. ${ }^{25,26}$

Developing intensification/general guidelines campaigns, cited by part of the health professionals, are opportunities to promote and prevent diseases and also for the screening of individuals in vulnerability and early detection of harms to health. However, one must consider the cultural particularities and the different logical processes prevailing in each socio-cultural context. $^{5}$

In the present study, we did not evaluate group health education activities and campaigns/guidelines considered the socio-cultural context of the territory, considering that most of these opportunities of health education practices were anchored to the national panorama of health needs and focused on the disease or health problems presented by users and communities and not as change agents and autonomy promotion of involved subjects. The lack of adequate planning was limited, with regard to users' needs and the necessary logistical aspects, since managers or centralized management, without the evaluation of the local need, directed most of the themes addressed to the activities.

The health professionals narrated the participation in health programs in the school, however the poisoning event, within the referential of the school health promoter, ${ }^{27}$ must go beyond school walls. The participation of all those responsible, including health professionals in the education sector and the community, is essential, forming work fronts so that everyone is alerted and mobilized for the benefit of the children. ${ }^{25,26}$

It is noteworthy that in this study nurses did not approach the child care consultation as a space for the prevention of poisoning and other accidents in children, a fact that is worrying, considering that childcare is an appropriate time to carry out health education activities and thus promote child health. ${ }^{28}$ In this sense, it should be pointed out that the prevention of accidents, with an emphasis on poisoning, should be one of the focuses of childcare performed by nurses and should be linked to the assessment of child growth and development, considering the specific risk of each phase of child development. 
For the development of health education activities in the context of childhood poisonings, one must consider the social, economic and cultural issues that are embedded the individuals involved in the health education process. It is necessary to take precedence over a humanized practice, privileging health promotion, against the curative model, with emphasis on the principles of integrality and equity, anchored in Freire presuppositions - dialogue, participation, and autonomy - as a possible way to reorganize assistance and health education practices in health. ${ }^{7}$

The context, in which the research was carried out, in a case study with FHS teams from a municipality with its own characteristics, may represent its limitation. However, the interviewees shared professional and social characteristics verified in national-based studies and maintained a relationship with health promotion and education themes similar to the discussions with depth or generalization in several studies.

\section{FINAL CONSIDERATIONS}

This work made it possible to analyze the health education practices carried out by health professionals of the Family Health Strategy team in the context of child poisoning, identifying that the practices were generally based on the concept of first aid and did not discuss the family as the center of the professional action. Those who admitted to working partly with accident prevention argued that more knowledge on the subject was needed. This situation can be attributed to the overload of health issues and problems/needs under the responsibility of health health professionals, causing them to value problems differently in work practice, or even considering the territorial practice of FHS, child poisoning/accidents not a local problem for several teams.

Considering the importance of the study, the results suggest reflections about the training in health education offered to Primary Care health professionals and how they are understood. It should be noted that the municipality studied has a history of actions aimed at permanent education as a training proposal. However, health professionals reported only little participation in courses and training and indicated in the health education practice report that the health promotion guidelines are not always implemented.

It is also emphasized that there are gaps to be explored in future studies, considering the existence of the hierarchy of values shared among the members of the teams, demonstrated in this study by all professional categories, seeking to overcome the authoritarian posture and knowledge holder for an integral and shared care among health professionals. Also, the study envisages the possibility of research that exposes care to child poisoning, and it is up to health health professionals to know and establish interventions other than first aid to the intoxicated, through the process of action-reflection-action, articulating knowledge and practices among the health professionals and families.

\section{FINANCIAL SUPPORT}

Master's scholarship granted to Camila Cristiane Formaggi Sales, by the Coordination for the Improvement of Higher Education Personnel - Brazil (CAPES) - Funding Code 001, timeframe March/2015 to February/2017. Publication fee paid by the State University of Maringá, process number 70642/2018.

\section{REFERENCES}

1. Sirohi S, Dhruvendra P, Dixit S, Chakresh J, Deshmankar B, Raja RS Domestic accidents: an emerging threat to community. Int J Med Sci Public Health [Internet]. 2015; [cited 2017 Oct 22]; 4(9):1202-5. Available from: https://www.ejmanager.com/fulltextpdf.php?mno=177527

2. Emery CR, Nguyen HT, Kim J. Understanding child maltreatment in Hanoi: intimate partner violence, low self-control, and social and child care support. J Interpers Violence [Internet]. 2014 May; [cited 2017 Nov 1];29(7):1228-57. Available from: http://journals.sagepub.com/doi/ pdf/10.1177/0886260513506276

3. Tavares EO, Buriola AA, Santos JAT, Ballani TSL, Oliveira MLF. Factors associated with poisoning in children. Esc Anna Nery [Internet].2014 Jan/ Mar; [cited 2017 Nov 1]; 17(1):31-7. Available from: http://www.scielo. br/scielo.php?script=sci_arttext\&pid=S1414-81452013000100005

4. Berra S, Rocha KB, Rodríguez-Sanz M, Pasarín MI, Rajmil L, Borre $\mathrm{C}$, et al. Properties of a short questionnaire for assessing primary care experiences for children in a population survey. BMC Public Health [Internet]. 2011 May; [cited 2017 Oct 30]; 11:285. Available from: https:// www.ncbi.nlm.nih.gov/pubmed/21554717

5. Mantovani MF, Mendes FRP, Ulbrich EM, Silva JVM, Wall ML, Reis BK Representations of health education for a team Family health strategy. Ciênc Cuid Saúde [Internet]. 2014 Jun/Sep; [cited 2017 Nov 22] 13(3):464-70. Available from: http://periodicos.uem.br/ojs/index.php/ CiencCuidSaude/article/viewFile/19142/pdf_329

6. Pereira VR, Coimbra VCC, Cardoso CS, Oliveira NA, Vieira ACG, Nobre $\mathrm{MO}$, et al. Participatory methodologies in research with children: creative and innovative approaches. Rev Gaúcha Enferm [Internet]. 2016; [cited 2017 Nov 1]; 37(Spe):e67908. Available from: http://www.scielo.br/pdf/ rgenf/v37nspe/0102-6933-rgenf-1983-14472016esp67908.pdf

7. Freire $P$. Pedagogia da autonomia: saberes necessários à prática educativa. São Paulo (SP): Paz e Terra; 2016.

8. Prado ML, Velho MB, Espíndola DS, Hilda Sobrinho S, Backes VMS Charles Maguerez Arc: reflecting methodology strategies on active training for health professionals. Esc Anna Nery [Internet]. 2012 Mar [cited 2017 Nov 22]; 16(1):172-7. Available from: http://www.scielo.br/ scielo.php?script=sci_arttext\&pid=S1414-81452012000100023

9. Sardinha Peixoto L, Cuzatis Gonçalves L, Dutra Da Costa T, Tavares CMM, Dantas Cavalcanti AC, Antunes Cortez E. Educación permanente, continua y en servicio; desvelando sus conceptos. Enferm Glob [Internet]. 2013; [cited 2017 Nov 1]; 12(29):324-40. Available from: http:// revistas.um.es/eglobal/article/view/141801/144121

10. Kash S, Dessinger JC. Paulo Freire's relevance to online instruction and performance improvement. Performance Improvement [Internet]. 2010 Feb; [cited 2017 Nov 1]; 49(2):17-21. Available from: http://onlinelibrary. wiley.com/doi/10.1002/pfi.20129/pdf

11. Melo CZC, Sousa CMB, Silva MBC. Contribuições de estudos sobre a assistência de enfermagem ao familiar do doente mental. Rev Saúde Foco [Internet]. 2014 Aug/Dec; [cited 2017 Nov 1]; 1(2):26-40. Available from: http://www4.fsanet.com.br/revista/index.php/saudeemfoco/article/ view/256

12. Alves LHS, Boehs AE, Heidemann ITSB. Family health strategy professionals and users' perception on health promotion groups. Texto Contexto Enferm [Internet]. 2012 Apr/Jun; [cited 2017 Nov 1];21(2):4018. Available from: http://www.scielo.br/scielo.php?script=sci_arttext\&p d=S0104-07072012000200019 
13. Ministério da Saúde (BR). Secretaria de Atenção à Saúde. Departamento de Atenção Básica. Política Nacional de Atenção Básica. Brasília (DF): Ministério da Saúde; 2012.

14. Minayo MCS. O desafio do conhecimento: pesquisa qualitativa em saúde. 14를 ed. São Paulo (SP): Hucitec; 2015.

15. Machado MH, Aguiar Filho W, Lacerda WF, Oliveira E, Lemos W, Wermelinger $\mathrm{M}$, et al. Características gerais da enfermagem: o perfil sócio demográfico. Enferm foco [Internet]. 2016; [cited 2017 Nov 1]; 7(Esp):9-14. Available from: http://revista.cofen.gov.br/index.php/ enfermagem/article/view/686/0

16. Breysse P, Farr N, Galke W, Lanphear B, Morley R, Bergofsky L. The relationship between housing and health: children at risk. Environmental Health Perspectives [Internet]. 2014 Aug; [cited 2017 Nov 1]; 112(15):1583-8. Available from: https://www.ncbi.nlm.nih.gov/ pmc/articles/PMC1247625/

17. Santana RA, Bochner R, Guimaraes MC. National poison information system: the challenge of the data standardization. Ciênc Saúde Coletiva [internet] 2011 [cited 2017 Jun 14]; 16(Suppl 1):1191-200. Available from: http://www.scielo.br/scielo.php?script=sci_arttext\&pi $d=S 1413-81232011000700051$

18. Olson KR, org. Manual de toxicologia clínica. [Internet] $6^{\mathrm{a}}$ ed. Porto Alegre (RS): McGraw Hill/Artmed; 2014 [cited 2017 Jun 14]. Available from: http://www.saude.ufpr.br/portal/medtrab/wp-content/uploads/ sites/25/2016/08/Manual-de-Toxicologia-Cl\%C3\%ADnica_pdf.pdf

19. Hoffman RS, Howland MA, Lewin NA, Nelson LS, Goldfrank LR. Goldfrank's Toxicologic Emergencies. 10th ed. New York (NY): McGraw Hill; 2015.

20. Ministério da Saúde (BR). Secretaria de Vigilância em Saúde. Secretaria de Atenção à Saúde. Política Nacional de Promoção da Saúde. Brasília (DF): Ministério da Saúde; 2015.

21. Batista PSS, Vasconcelos EM, Costa SFG. Ethics in health education and health care actions oriented by popular education. Interface (Botucatu) [Internet]. 2014; [cited 2017 Nov 1]; 18(Suppl 2):1401-12. Available from: http://www.scielo.br/scielo.php?script=sci_arttext\&pid $=$ S1414-32832014000601401
22. Filgueiras AS, Silva ALA. Agente Comunitário de Saúde: um novo ator no cenário da saúde do Brasil. Physis [Internet]. 2011 Jan; [cited 2018 Oct 15]; 21(3):899-916. Available from: http://www.scielo.br/scielo. php?script=sci_arttext\&pid=S0103-73312011000300008

23. Adler MS, Gallian DMC. Formação médica e serviço único de saúde: propostas e práticas descritas na literatura especializada. Rev Bras Educ Med [Internet]. 2014 Sep; [cited 2017 Nov 22]; 38(3):388-96. Available from: http://www.scielo.br/pdf/rbem/v38n3/14.pdf

24. Sales CCF, Suguyama P, Guedes MRJ, Borghesan NBA, Higarash $\mathrm{IH}$, Oliveira MLF. Intoxicação na primeira infância: socorros domiciliares realizados por adultos. Rev Baiana Enferm [Internet]. 2017;31(4):e23766. Available from: https://portalseer.ufba.br/index. php/enfermagem/article/view/23766

25. Andrade VMP, Cardoso CL. Visitas Domiciliares de Agentes Comunitários de Saúde: Concepções de Profissionais e Usuários. Psico-USF [Internet]. 2017 Jan; [cited 4 Jul 2018]; 22(1):87-98. Available from: http://www.scielo.br/pdf/pusf/v22n1/2175-3563pusf-22-01-00087.pdf

26. Vieira LJES, Carneiro RCMM, Frota MA, Gomes ALA, Ximenes LB. Actions and possibilities of accidents prevention with children in daycare at Fortaleza, Ceará State. Ciênc Saúde Coletiva [Internet]. 2009; [cited 2018 Oct 15]; 11(5):1687-97. Available from: http://www.scielo.br/scielo. php?script=sci_arttext\&pid=S1413-81232009000500010

27. Liberal EF, Aires RT, Aires MT, Osório ACA. Safe school. J Pediatr (Rio J) [Internet]. 2005 Nov [cited 2017 Nov 1]; 81 (5 Suppl):S155-63. Available from: http://www.scielo.br/pdf/jped/v81n5s0/en_v81n5Sa05. pdf

28. Suto CSS, Laura TAOF, Costa LEM. Puericultura: a consulta de enfermagem em Unidades Básicas de Saúde. Rev Enferm UFPE [Internet]. 2014 Sep; [cited 2018 Jul 4]; 8(9):3127-33. Available from: https://periodicos.ufpe.br/revistas/revistaenfermagem/article/ view/10034/10432 